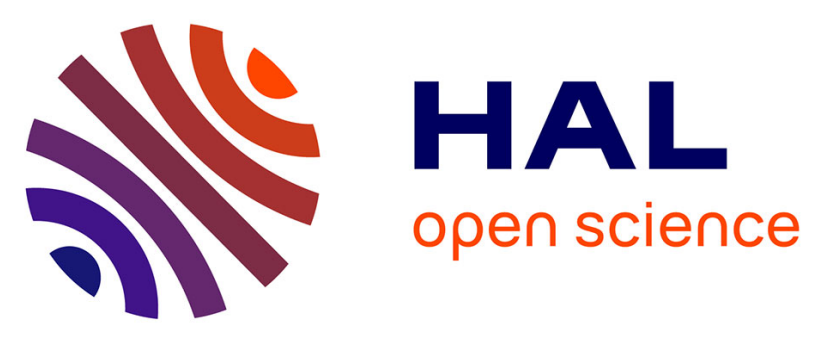

\title{
Expression of adipokines and estrogen receptors in adipose tissue and placenta of patients with gestational diabetes mellitus
}

P. Kleiblova, I. Dostalova, M. Bartlova, Z. Lacinova, I. Ticha, V. Krejci, D. Springer, Z. Kleibl, M. Haluzik

\section{To cite this version:}

P. Kleiblova, I. Dostalova, M. Bartlova, Z. Lacinova, I. Ticha, et al.. Expression of adipokines and estrogen receptors in adipose tissue and placenta of patients with gestational diabetes mellitus. Molecular and Cellular Endocrinology, 2009, 314 (1), pp.150. 10.1016/j.mce.2009.08.002 . hal-00529007

\section{HAL Id: hal-00529007 https://hal.science/hal-00529007}

Submitted on 24 Oct 2010

HAL is a multi-disciplinary open access archive for the deposit and dissemination of scientific research documents, whether they are published or not. The documents may come from teaching and research institutions in France or abroad, or from public or private research centers.
L'archive ouverte pluridisciplinaire HAL, est destinée au dépôt et à la diffusion de documents scientifiques de niveau recherche, publiés ou non, émanant des établissements d'enseignement et de recherche français ou étrangers, des laboratoires publics ou privés. 


\section{Accepted Manuscript}

Title: Expression of adipokines and estrogen receptors in adipose tissue and placenta of patients with gestational diabetes mellitus

Authors: P. Kleiblova, I. Dostalova, M. Bartlova, Z. Lacinova, I. Ticha, V. Krejci, D. Springer, Z. Kleibl, M. Haluzik



PII: S0303-7207(09)00405-5

DOI: doi:10.1016/j.mce.2009.08.002

Reference: MCE 7282

To appear in: $\quad$ Molecular and Cellular Endocrinology

Received date: $\quad$ 12-5-2009

Revised date: $\quad$ 27-7-2009

Accepted date: $\quad$ 5-8-2009

Please cite this article as: Kleiblova, P., Dostalova, I., Bartlova, M., Lacinova, Z., Ticha, I., Krejci, V., Springer, D., Kleibl, Z., Haluzik, M., Expression of adipokines and estrogen receptors in adipose tissue and placenta of patients with gestational diabetes mellitus, Molecular and Cellular Endocrinology (2008), doi:10.1016/j.mce.2009.08.002

This is a PDF file of an unedited manuscript that has been accepted for publication. As a service to our customers we are providing this early version of the manuscript. The manuscript will undergo copyediting, typesetting, and review of the resulting proof before it is published in its final form. Please note that during the production process errors may be discovered which could affect the content, and all legal disclaimers that apply to the journal pertain. 


\title{
Expression of adipokines and estrogen receptors in adipose tissue and placenta of patients with gestational diabetes mellitus
}

\author{
Kleiblova P. ${ }^{1}$, Dostalova I. ${ }^{2}$, Bartlova M. ${ }^{2}$, Lacinova Z. ${ }^{2}$, Ticha I. ${ }^{1}$, Krejci V. ${ }^{3}$, Springer D. ${ }^{4}$, \\ Kleibl Z. ${ }^{1}$ and Haluzik M. ${ }^{2}$ \\ ${ }^{1}$ Institute of Biochemistry and Experimental Oncology, 1st Faculty of Medicine, Charles \\ University, Prague, Czech Republic. \\ ${ }^{2} 3 r d$ Department of Medicine, 1st Faculty of Medicine, Charles University and General \\ University Hospital, Prague, Czech Republic. \\ ${ }^{3}$ Department of Obstetrics and Gynecology, 1st First Faculty of Medicine, Charles University \\ and General University Hospital, Prague, Czech Republic. \\ ${ }^{4}$ Department of Clinical Biochemistry and Laboratory Medicine, 1st First Faculty of \\ Medicine, Charles University and General University Hospital, Prague, Czech Republic
}

\section{Corresponding author:}

Martin Haluzik, Prof, MD, PhD

$3^{\text {rd }}$ Department of Medicine, $1^{\text {st }}$ Faculty of Medicine

U Nemocnice 1

12808 Prague 2

Czech Republic

Tel.: + 420 224962908; Fax: + 420224919780

e-mail: mhalu@lf1.cuni.cz

Key words: gestational diabetes mellitus; subcutaneous adipose tissue; visceral adipose tissue; placenta; leptin; estrogen receptors. 


\section{SUMMARY}

The purpose of this study was to assess the expression profile of genes with potential role in the development of insulin resistance (adipokines, cytokines/chemokines, estrogen receptors) in subcutaneous adipose tissue (SAT), visceral adipose tissue (VAT) and placenta of pregnant women with gestational diabetes mellitus (GDM) and age-matched women with physiological pregnancy at the time of Caesarean section. qRT-PCR was used for expression analysis of the studied genes. Leptin gene expression in VAT of GDM group was significantly higher relative to control group. Gene expressions of interleukin-6 and interleukin-8 were significantly increased, whereas the expressions of genes for estrogen receptors $\alpha$ and $\beta$ were significantly reduced in SAT of GDM group relative to controls, respectively. We found no significant differences in the expression of any genes of interest (LEP, RETN, ADIPOR1, $A D I P O R 2, T N F-\alpha, C D 68, I L-6, I L-8, E R \alpha, E R \beta)$ in placentas of women with GDM relative to controls. We conclude that increased expression of leptin in visceral adipose depot together with increased expressions of proinflammatory cytokines and reduced expressions of estrogen receptors in subcutaneous fat may play a role in the etiopathogenesis of GDM. 


\section{INTRODUCTION}

Gestational diabetes mellitus (GDM) is the most frequent metabolic disorder in pregnancy, affecting 1-10\% of all pregnancies (Beischer et al., 1996 and Gabbe, 1986). Although most of the women with GDM return to normal glucose tolerance after delivery, they still have significantly increased risk of developing diabetes later in life (Kim et al., 2002). GDM is considered a prediabetic state, therefore it may display many abnormalities that possibly appear in the very early stages of type 2 diabetes mellitus (T2DM) (Pendegrass et al., 1995). In addition to mechanisms similar to patients with T2DM (Friedman et al., 1999 and Catalano et al., 2002), the etiopathogenesis of GDM includes the combination of the disturbed endocrine function of adipose tissue and placenta (Coughlan et al., 2001; Cseh et al., 2002; Kirwan et al., 2002; Radaelli et al., 2003; Ranheim et al., 2004 and Meller et al., 2006), and the systemic hormonal changes affecting insulin sensitivity in peripheral tissues (Barros et al., 2008).

Adipokines [leptin (LEP; OMIM 164160), resistin (RETN; OMIM 605565), and adiponectin (ADIPOQ; OMIM 605441)], inflammatory cytokines [tumor necrosis factor- $\alpha$ (TNF- $\alpha$; OMIM 191160), and interleukin-6 (IL-6; OMIM 147620)], and chemokines [interleukin-8 (IL-8; OMIM 146930)] have been implicated in the etiopathogenesis of insulin resistance and in the early defects of T2DM (Bastard et al., 2000; Moller, 2000; Wauters et al., 2000; Coppack, 2001; Kern et al., 2001; Steppan et al., 2001; Weyer et al., 2001; Greenberg and McDaniel, 2002; Havel, 2002; Housa et al., 2006; Kleiblova et al., 2006 and Lamounier-Zepter et al., 2008). Leptin, adiponectin and $T N F$ - $\alpha$ have been suggested as much stronger predictors of pregnancy-associated insulin resistance than gestational hormones, including human placental lactogen and steroids (Lepercq et al., 1998; Kirwan et al., 2002 and Radaelli et al., 2003). In previously published studies, circulating levels of leptin, adiponectin 
and $T N F-\alpha$ in the early pregnancy closely predicted the development of GDM (Qiu et al., 2004; Hernandez Valencia et al., 2005; Maghbooli et al., 2007 and Gao et al., 2008).

To our best knowledge, the contribution of different fat depots (subcutaneous and visceral) to altered levels of adipokines and cytokines in GDM is unknown. Studies of patients with obesity and/or T2DM have shown that metabolic and endocrine characteristics of adipose tissue significantly vary between different locations (Wajchenberg, 2000; Coppack, 2001; Wagenknecht et al., 2003 and Dolinkova et al., 2008). Placenta of patients with GDM typically displays structural and functional abnormalities (Alonso et al., 2006) suggesting possible alterations in its endocrine function including disturbed production of adipokines and/or proinflammatory factors (Masuzaki et al., 1997; Radaelli et al., 2003 and Yura et al., 2003). Previous reports confirmed that GDM elicits major changes in the expression profile of placental genes with a prominent increase in markers and mediators of inflammation (Radaelli et al., 2003).

We hypothesized that dysregulated endocrine function of adipose tissue and placenta during pregnancy may contribute to the development of insulin resistance and GDM. The aim of the present study was to characterize the changes in gene expression of adipokines [leptin, resistin, adiponectin and its receptors - adiponectin receptor 1 (ADIPOR1; OMIM 607945), and adiponectin receptor 2 (ADIPOR2; OMIM 607946)], proinflammatory cytokines (IL-6, $T N F-\alpha)$, chemokines $(I L-8)$ and other receptors with potential role in the regulation of glucose and lipid homeostasis [genes for peroxisome proliferator-activated receptor- $\alpha$ (PPAR- $\alpha$; OMIM 170998), estrogen receptor $\alpha$ (ESR1, ER $\alpha$; OMIM 133430), and estrogen receptor $\beta$ (ESR2, ER $\beta$; OMIM 601663)] in subcutaneous and visceral adipose tissue and placenta of patients with gestational diabetes mellitus relative to those in healthy women with physiological pregnancy. 


\section{PATIENTS AND METHODS}

Study subjects

Ten women with GDM (age $34.6 \pm 2.50$ years) and thirteen healthy age-matched women with physiological pregnancy (age $33.1 \pm 1.25$ years) were included in the study. Only women with single pregnancy who delivered by planned Cesarean section in the term (40 \pm 2 weeks of pregnancy) were enrolled into the study. All GDM were treated by intensive insulin therapy. All women enrolled into the study underwent the 75-gram 2-hour oral glucose tolerance test (oGTT) between 24th and 28th week of their pregnancy. Physiological ranges of glycemia were set according to Recommendations of the Czech Diabetes Association as follows: fasting glycemia $<5.5 \mathrm{mmol} / \mathrm{l}$, glycemia 1 hour after glucose ingestion $<8.8 \mathrm{mmol} / \mathrm{l}$ and glycemia 2 hours after glucose ingestion $<7.6 \mathrm{mmol} / \mathrm{l}$. The positive oGTT and a need for insulin treatment were the inclusion criteria for GDM group. None of GDM patients had history of diabetes and impaired glucose tolerance before pregnancy. All women had normal fasting glucose levels at the beginning of the pregnancy. The study, performed in accordance with the quidelines proposed in the Declaration of Helsinki, was approved by the Ethical Commitee, First Faculty of Medicine, and General University Hospital, Prague, Czech Republic, and all participants signed written informed consent before being enrolled in the study.

Anthropometric examination and blood sampling 
All subjects were measured and weighted and their body mass index (BMI) was calculated twice for the study need; at the beginning of pregnancy (these data as well as serum glucose concentrations were obtained retrospectively from maternity card) and 3rd day after delivery at the Department of Obstetrics and Gynecology.

Body fat content was estimated by bioimpedance measurement (Body Fat Monitor, BF 306, Omron) 3rd day after delivery at the same time as body weight and BMI were estimated.

All maternal and fetal blood and maternal tissue samples were collected at the time of delivery. At the beginning of Caesarean section blood drawings (13 $\mathrm{ml}$ of blood) were performed. Serum samples for insulin, adipokine and cytokine measurements as well as for all other examinant biochemical parameters were obtained by centrifugation and whole blood samples for glycated hemoglobin measurements were withdrawn. After manual removal of placenta, $5 \mathrm{ml}$ of fetal umbilical blood was also obtained for serum separation. All serum samples were stored in aliquots at $-80^{\circ} \mathrm{C}$ until further analysis.

\section{Hormonal and biochemical assays}

Serum adiponectin concentrations were measured by Human Adiponectin ELISA kit (Linco Research, USA) with intra- and inter-assay variability of (1.0 - 7.4\%) and (2.4 - 8.4\%), respectively. Serum leptin and resistin concentrations were measured by commercial ELISA kits (BioVendor, Brno, Czech Republic). Sensitivity was $0.2 \mathrm{ng} / \mathrm{ml}$ for resistin and $0.12 \mathrm{ng} / \mathrm{ml}$ for leptin, and the intra- and interassay variability were $<5 \%$ and $<8 \%$, respectively. Serum insulin concentractions were measured by commercial RIA kit (Cis Bio International, Gif-surYvette Cedex, France). Sensitivity was $2.0 \mu \mathrm{IU} / \mathrm{ml}$ and the intra- and interassay variability were $4.2 \%$ and $8.8 \%$, respectively. 
Biochemical parameters were measured in the Department of Clinical Biochemistry and Laboratory Medicine, General University Hospital and First Faculty of Medicine, Charles University in Prague, by standard laboratory methods. Serum glucose concentrations were measured by photometric enzyme assay GOD/POD (Pliva - Lachema), serum triglyceride concentrations were measured by photometric enzyme assay GPO/PAP (Human Gesellschaft für Biochemica und Diagnostica mbH) and serum C-peptide concentrations were measured by electrochemiluminiscence - all of them on the MODULAR System (ROCHE Diagnostics). Serum estradiol concentrations were measured by two-step immunoassays using Chemiluminiscent Microparticle Immunoassay (CMIA) technology with flexible assay protocols, referred to as ChemiflexTM. System: Architect i2000 (ABBOTT Laboratories).

\section{Tissue samples}

Subcutaneous adipose tissue (SAT) from the region of transverse Pfannenstiel incision and visceral (omental) adipose tissue (VAT) samples were obtained during surgery and placental tissue was sampled after manual removal of placenta from approximately $5 \mathrm{~mm}$ deep incision from fetal side of placenta in the central part of cotyledon. All samples were immediately immersed into RNAlater (Qiagen) and were stored according to manufacturer instructions until total RNA isolation.

Total RNA isolation and $c D N A$ sample preparation

Total RNA from SAT and VAT were isolated using RNeasy Lipid Tissue Mini Kit (Qiagen) and placental total RNA was isolated by RNeasy Protect Mini Kit (Qiagen) according to manufacturer protocols. Quality of isolated RNA was controlled 
spectrophotometrically (only the samples with 260/280 nm ratio >1.8 were proceed for further steps of analysis), the RNA integrity was controlled by agarose gel electrophoresis. RNA samples were stored at $-80^{\circ} \mathrm{C}$ until cDNA preparation.

All RNA samples were treated by DNase (Fermentas) prior cDNA synthesis. Reverse transcription was performed in $40 \mu \mathrm{l}$ reaction volume with $4 \mu \mathrm{l}$ (placenta) and $2 \mu \mathrm{l}$ (SAT and VAT) template total RNA, respectively, using SuperScript III reverse transcriptase (Invitrogen) and random hexanucleotides (Roche) according to manufacturer Synthetized cDNA was stored at $-20^{\circ} \mathrm{C}$ until qPCR.

Real-time PCR (qPCR) and gene expression quantification

Gene expression was analyzed by quantitative real-time RT-PCR (qPCR) and quantified by REST (Relative Expression Software Tool) 2008 ver. 2.0.7 (Corbett Research Pty. Ltd) (Pfaffl, 2001 and Pfaffl et al., 2002) and/or by qGENE softwares.

Commercially designed primers were used for CD68, ESR1, ESR2, IL-6, IL-8, RETN and $T N F$ - $\alpha$ genes (SuperArray, USA), whereas primers for amplification of other genes were designed by us and synthetized by Generi Biotech, Czech Republic: B2M forward (5'ATGTCTCGCTCCGTGGCCTTA-3’), reverse (5’-TCGGATGGATGAAACCCAGACACA3’); GAPDH forward (5'-GGTGAAGGTCGGAGTCAACGG-3’), reverse (5’CGCTCCTGGAAGATGGTGATGG-3’); $\quad P B G D \quad$ forward $\quad$ (5’ATGTCTGGTAACGGCAATGCGG-3’), reverse (5’-TGTCCCCTGTGGTGGACATAGC3’); $A D I P O Q$ forward (5'-GTGATGGCAGAGATGGCACCC-3'), reverse (5’AGGCACCTTCTCCAGGTTCTCC-3'); ADIPOR1 forward (5'TTGTGTACAAGGTCTGGGAGGGA-3’), $\quad$ reverse (5’CAGCACGAAACCAAGCAGATGG-3'); ADIPOR2 forward (5'CTGATGGCCAGCCTCTACATCAC-3'), reverse (5'-CCCGCCGATCATGAAACGAAAC- 
3’) LEP forward (5'-CTATGTCCAAGCTGTGCCCATCC-3'), reverse (5’CTGCCAGTGTCTGGTCCATCTTG-3’); $\quad P P A R-\alpha \quad$ forward $\quad$ (5’CGCAATCCATCGGCGAGGATA-3'), reverse (5’-CTCCACTGGGAGACTCGTCCA-3'). The size of PCR amplicons of all tested genes ranged between 100 and 230bp. PCR product specificity for primers designed in our laboratory was confirmed by DNA sequencing (BigDye Terminator ver 3.1; Applied Biosystems) of PCR amplicons. The qPCR reaction containing $1 \mu \mathrm{l}$ of cDNA and $4 \mathrm{pmol}$ of each primer was carried out in $10 \mu \mathrm{l}$ reaction volume using SybrGreen LightCycler FastStart DNA Master SYBR Green I (Roche) on LightCycler 2.0 (Roche) according to manufacturer instructions. The $\mathrm{MgCl}_{2}$ concentrations (in range 1.75 -4.0 mmol. $\left.\mathrm{l}^{-1}\right)$ were optimized for each type of qPCR. qPCR was run in 45 cycles $\left(95^{\circ} \mathrm{C} 10 \mathrm{~s}\right.$; $\left.60^{\circ} \mathrm{C} / 66^{\circ} \mathrm{C} 10 \mathrm{~s} ; 72^{\circ} \mathrm{C} 10 \mathrm{~s}\right)$ with initial denaturation $\left(95^{\circ} \mathrm{C}\right.$ for $\left.10 \mathrm{~min}\right)$. Control of amplification specificity was routinely performed by implementation of melting analysis (72$95^{\circ} \mathrm{C}$ ) at the end of each qPCR run and agarose gel electrophoresis of generated amplicons. All analyses were performed in doublets involving simultaneously analyzed negative controls for all types of analyzed amplicons.

The calibration curves using serial dilutions of control cDNA $(200,100,50,25,10,1$, and 0.1 ng of cDNA) were prepared for each amplicon enabling assessment of qPCR efficiencies calculated by REST 2008 ver. 2.0.7 software.

The qGENE software (considering qPCR efficiency for each type of reaction) was used for relative quantification of analyzed genes against selected housekeeping gene (beta-2microglobulin; $B 2 M$ ). This software allowed quantification of relative gene expression of each individual analyzed sample, but only to just one housekeeping gene.

Changes in expression of analyzed genes between tested cohorts (women with GDM and healthy pregnant women), as well as between tested tissue types (SAT, VAT, placenta) were compared using REST 2008 ver. 2.0.7 considering qPCR efficiency for each type of reaction. 
The results from REST 2008 ver. 2.0.7 were obtained as mean expression ratios and 95\% confidence intervals of the relative expressions of target genes. For relative quantification and normalization of gene expression analyses done by REST 2008 ver. 2.0.7, we used three housekeeping genes: $B 2 M$, glyceraldehyde-3-phosphate dehydrogenase (GAPDH; OMIM 138400), and porphobilinogen deaminase (PBGD; OMIM 609806), which minimized wrong results interpretation.

\section{Statistical analysis}

Pair Wise Fixed Reallocation Randomisation Test, a part of REST 2008 ver. 2.0.7 (Pfaffl et al., 2002), was used for the statistical analysis of gene expression changes (described in detail on http://www.gene-quantification.info/). Other data were analyzed by SigmaStat software for statistical analyses (SPSS Inc., Chicago, IL). Anthropometric, biochemical and hormonal results are expressed as means \pm SEM. Differences between studied groups (GDM vs. controls) were evaluated by unpaired t-test or Mann-Whitney test as appropriate. The correlations between the values were estimated by Spearman correlation test. Statistical significance was set to $p<0.05$.

\section{RESULTS}

Anthropometric characteristic of healthy women with physiological pregnancy and pregnant women with gestational diabetes mellitus (GDM) and their newborns

The study groups were age-matched. Pregnant women with GDM had significantly higher BMI before pregnancy, higher BMI third day after delivery, and higher percentage of body fat 
third day after delivery relative to control group. Birth weight, birth length and birth wigth/length ratio of the newborns did not differ beween the groups (Table 1).

Maternal and fetal serum biochemical and hormonal parameters of GDM and control group

Maternal serum levels of adiponectin, resistin, C-peptide, triglycerides, and estradiol did not significantly differ in GDM group as compared with control group. Maternal serum leptin levels tended to be higher in GDM group, but the difference did not reach the statistical significance $(p=0.1)$. Serum glucose, insulin, and glycated hemoglobin levels were significantly higher in GDM relative to control group. Fetal serum adiponectin, resistin, and insulin levels did not significantly differ between GDM group and control group, whereas fetal serum leptin levels were markedly increased in GDM group as compared to control group. In both groups, fetal adiponectin concentrations were higher compared to maternal adiponectin concentrations (71.3 \pm 8.9 vs. $22.7 \pm 1.9$ mg..$\left.^{-1} ; p<0.00001\right)$. The opposite was true for leptin concentrations that were higher in maternal relative to fetal serum samples $\left(15.0 \pm 3.4\right.$ vs. $\left.29.1 \pm 4.1 \mu \mathrm{g} \mathrm{l^{-1 }} ; p=0.01\right)$. Serum concentrations of resistin and insulin did not significantly differ between mothers and their newborns (Table 2).

Gene expression in subcutaneous adipose tissue, visceral adipose tissue, and placenta: comparison of women with GDM and healthy control pregnant women

Gene expression of resistin, adiponectin, ADIPOR1, ADIPOR2, PPAR- $\alpha, T N F-\alpha$, and CD68 did not significatly differ between GDM and control group in any tissue studied. Leptin gene expression was 3.5-times higher in VAT of GDM group relative to control group. mRNA levels of $I L-6$ and $I L-8$ were 6.3-times and 4.8-times higher in SAT of GDM group as 
compared to control group. On the contrary, the expressions of $E R \alpha$ and $E R \beta$ were significantly lower in SAT of GDM group as compared with control group (Figure 1, Table 3). Gene expression of adiponectin was undetectable in placenta (Table 3).

The comparison of the relative expression of the studied genes between subcutaneous adipose tissue, visceral adipose tissue and placenta

The proportion of relative gene expression (normalized to $B 2 M$ ) of all analyzed genes in all three tested tissues is summarized in Figure 2.

The expressions of genes for leptin, adiponectin, and ER $\beta$ were significantly higher in SAT than in VAT in both GDM and control groups. Gene expressions of resistin, ADIPORI and ADIPOR2 were significantly higher in SAT than in VAT in the control, but not in GDM group. Gene expression of $I L-8$ was significantly higher in SAT than in VAT in GDM group only. Gene expression of $I L-6$ was higher in VAT than in SAT in control group, whereas higher expression of $I L-6$ in SAT relative to VAT was found in GDM. Gene expression of $E R \alpha$ was significantly higher in SAT than VAT in control group, whereas it did not significantly differ between the SAT and VAT depots in GDM (Figure 2, Table 4).

The expressions of genes for leptin, $A D I P O R 2$ and $C D 68$ were significantly higher in SAT than in placenta in control group, but not in GDM group. The expressions of $I L-8, E R \alpha$ and $E R \beta$ were markedly higher in SAT than in placenta in both control and GDM group. The expression of $I L-6$ was significantly higher in SAT than in placenta in GDM group only. Inspite of undetectable adiponectin expression in placenta, the expression of ADIPOR1 was 3times higher in placenta than in SAT in both groups studied (Figure 2, Table 4).

\section{DISCUSSION}


The most important finding of this study is that visceral fat leptin gene expression and subcutaneous fat $I L-6$ and $I L-8$ gene expressions were significantly increased, whereas subcutaneous fat $E R \alpha$ and $E R \beta$ gene expressions were significantly decreased in women with GDM relative to healthy age-matched women with physiological pregnancy.

Inspite of previously suggested predictive role for leptin in the development of GDM (Qiu et al., 2004; Maghbooli et al., 2007 and Gao et al., 2008), there is still a controversy as far as the circulating levels of leptin in GDM are concerned (Festa et al., 1999; Kautzky-Willer et al., 2001 and Simmons et al., 2002). Such a discrepancy in published results could be attributed to the different gestational age at time of the maternal blood collection and the differences in severity of GDM and its compensation (Festa et al., 1999). Here we observed a strong, but non-significant, trend towards increased circulating leptin levels in the GDM group at the time of delivery. The lack of statistically significant difference between the groups could be at least partially attributable to a satisfactory diabetes compensation of GDM group at the time of blood collection as well as to relatively low number of subjects together with high interindividual circulating leptin concentrations variability.

Visceral fat has been shown to contribute to the development of impaired glucose metabolism in women with history of GDM (Lim et al., 2007). Markedly elevated expression of leptin in visceral adipose depot of women with GDM may thus play a role in the development of endocrine dysfunction of visceral fat and later on also in the development of GDM. The mechanism of leptin contribution to the development of insulin resistance may lie in its inhibitory effect on the insulin-signaling cascade; leptin promotes phosphorylation of Ser-318 in Irs1 by a janus kinase 2, Irs2, and PKC-dependent pathway (Hennige et al., 2006). Although the findings of majority (Lepercq et al., 1998; Lea et al., 2000; Radaelli et al., 2003 and Meller et al., 2006), but not all (Lappas et al., 2005), previous studies showed elevated leptin production in placenta from women with GDM, our results suggest that, at the time of 
delivery visceral adipose tissue, rather than a placental tissue, appears to be a major contributor to increased leptin levels in GDM. We also suggest that high maternal visceral fat leptin expression and significantly increased fetal serum leptin levels at the time of delivery could play a role in later susceptibility to the potential post-pregnancy development of insulin resistance and T2DM in both mother and fetus (McNeely et al., 1999; Jansson et al., 2002 and Shahid et al., 2008).

It still remains to be determined what factors trigger increased expression of leptin in visceral fat of women with GDM and whether these factors precede the development of insulin resistance and diabetes or are rather secondary to these metabolic disturbances. One possible contributor to increased leptin expression in visceral fat in GDM might be altered estrogen receptor subtypes expression ratio in adipose depots of GDM in response to rising estrogen level with advancing gestation (Sivan et al., 1998; Brann et al., 1999; Tanaka et al., 2001 and Yi et al., 2008). Here we found similarly to Yi and colleagues (Yi et al., 2008) a significant positive relationship of visceral adipose tissue leptin gene expression with visceral fat $E R \alpha$ gene expression ( $\mathrm{r}=0.68, p<0.00001$ ), as well as with visceral fat $E R \alpha / E R \beta \mathrm{mRNA}$ expression ratio in a combined population of both study groups $(\mathrm{r}=0.46, p=0.04)$. Although we found no significant relationship between $L E P$ and $E R \beta$ gene expressions in visceral fat depot, we found a significant positive relationship between $L E P$ and $E R \beta$ gene expressions (r $=0.56, p=0.009$ ) in subcutaneous adipose depot. Leptin mRNA level in visceral fat was also inversely related to maternal estradiol serum concentrations $(\mathrm{r}=-0.52, p=0.02)$. Furthermore, we found significantly different $E R \alpha / E R \beta$ ratio in subcutaneous over visceral fat depot between GDM and controls (SAT/VAT expression ratio of $E R \alpha / E R \beta$ : controls 1.34 vs. GDM 0.46, $p<0.05$ ). Shin et al. (2007) previously showed that the subcutaneous $E R \alpha / E R \beta$ over visceral $E R \alpha / E R \beta$ ratio is significantly positively associated with leptin expression in visceral fat depot. 
The second group of candidates possibly affecting leptin expression in visceral fat in pregnancy includes insulin and glucose (Boucher et al., 2005 and Salvatores et al., 2006). It has been previously documented that insulin increases leptin mRNA expression in human subcutaneous fat (Pratley et al., 2000). Mouse models of obesity, diabetes and insulin resistance have markedly increased adipose tissue leptin mRNA expression (Boucher et al., 2005). Here we showed that visceral fat leptin expression positively correlated with blood glucose $(r=0.52, p=0.02)$.

Thirdly, previous reports postulated that the release of leptin from maternal adipose tissue positively correlates with maternal BMI (Lappas et al., 2005). Here we found that visceral fat leptin gene expression positively correlated with maternal BMI before pregnancy $(\mathrm{r}=0.46, p$ $=0.04)$ and with maternal body weight $3^{\text {rd }}$ day after delivery $(\mathrm{r}=0.48, p=0.03)$.

Increasing evidence suggests that GDM is a proinflammatory state similarly as T2DM (Radaelli et al., 2003). Increased expression of $I L-6$ and $I L-8$ in subcutaneous adipose depot of women with GDM is in agreement with such idea and with previously described increased circulating levels of IL-6 and IL-8 in GDM (Kuzmicki et al., 2008). Interestingly, although visceral adipose tissue is traditionally considered more proinflammatory fat depot (Wajchenberg, 2000 and Wagenknecht et al., 2003) here we found that in GDM patients mRNA expression of $I L-6$ was higher in subcutaneous than in visceral fat. Even more strikingly, the opposite was true for healthy control group. We also observed significantly lower mRNA expression of $I L-6$ in placenta than in subcutaneous fat of GDM patients, but not in controls, which further indicates altered inflammatory status regulation in patients with GDM. We have also showed that maternal adipose tissue $I L-6$ expression positively correlates with fetal serum leptin $(\mathrm{r}=0.52, p=0.01)$ and that placental $I L-8$ mRNA inversely correlates with fetal serum resistin $(r=-0.50, p=0.03)$, suggesting that proinflammatory state of the 
mother may influence the endocrine regulations of the fetus (Henson and Castracane, 2002 and Nathanielsz et al., 2007).

The results of our study underline a possible importance of estrogen receptors in the regulation of insulin resistance. In experimental studies, ER $\alpha$ activation appears to protect against insulin resistance while the opposite is generally true for $\operatorname{ER} \beta$ activation (Naaz et al., 2002 and Foryst-Ludwig et al., 2008). The selective knock-out of ER $\alpha$ led to adipocyte hyperplasia and hypertrophy, insulin resistance, and glucose intolerance in mice (Heine et al., 2000). In mature adipocytes $E R \alpha$ mRNA expression was higher as compared to $E R \beta$ mRNA levels, but $E R \beta$ is quantitavely more expressed isoform in women than in men (Deroo and Korach, 2006). Here we showed that at the time of delivery the $E R \beta$ gene expression is in all three analyzed tissues higher than $E R \alpha(E R \alpha / E R \beta=0.043$ in SAT, 0.078 in VAT and 0.322 in placenta; data not shown). We also showed that GDM is associated with decreased expression of both types of estrogen receptors in subcutaneous fat depot suggesting another possible mechanism of modulation of insulin sensitivity in these patients. Since $E R \alpha$ appears to play a major role in adipose tissue (Naaz et al., 2002) its decreased expression in subcutaneous fat of patients with GDM may contibute to the development of insulin resistance within this adipose tissue depot.

We are aware, that our study has several limitations. The first one is the relatively low number of subjects included and the presence of significantly higher BMI of GDM group relative to control group before the pregnancy. Second, rather paradoxical limitation from the patients' point of view is that all tissue samples were collected at the time of delivery when diabetes of GDM patients was satisfactorily-compensated which may have partially blunted the differences between the groups.

In conclusion, our study has shown that GDM is accompanied by increased expression of leptin in visceral adipose depot together with increased expression of proinflammatory 
cytokines and reduced expression of estrogen receptors in subcutaneous adipose depot. We suggest that these alterations may in concert contribute to some of metabolic disturbances seen in GDM patients not only during pregnancy but also after delivery. 


\section{Acknowledgements}

Supported by IGA MHCR no. 8302-5 to MH and PK. We thank to obstetricians and the patients for their collaboration. The special thank belongs to Mrs. Hana Vágnerová for help with the majority of tissue sampling. 


\section{References}

Alonso, A., Del Rey, C.G., Navarro, A., Tolivia, J., González, C.G., 2006. Effects of gestational diabetes mellitus on proteins implicated in insulin signaling in human placenta. Gynecol. Endocrinol. 22, 526-535.

Barros, R.P., Morani, A., Moriscot, A., Machado, U.F., 2008. Insulin resistance of pregnancy involves estrogen-induced repression of muscle GLUT4. Mol. Cell. Endocrinol. 295, 24-31.

Bastard, J.P., Maachi, M., Van Nhieu, J.T., Jardel, C., Bruckert, E., Grimaldi, A., Robert, J.J., Capeau, J., Hainque, B., 2002. Adipose tissue IL-6 content correlates with resistance to insulin activation of glucose uptake both in vivo and in vitro. J. Clin. Endocrinol. Metab. 87, 2084-2089.

Beischer, N.A., Wein, P., Sheedy, M.T., Dargaville, R.M., 1996. Effect of follow-up of women with gestational diabetes on the ratio of IDDM to NIDDM in pregnancy. Diabetes. Care. 19, 653-655.

Boucher, J., Castan-Laurell, I., Daviaud, D., Guigné, C., Buléon, M., Carpéné, C., SaulnierBlache, J.S., Valet, P., 2005. Adipokine expression profile in adipocytes of different mouse models of obesity. Horm. Metab. Res. 37, 761-767.

Brann, D.W., De Sevilla, L., Zamorano, P.L., Mahesh, V.B., 1999. Regulation of leptin gene expression and secretion by steroid hormones. Steroids. 64, 659-663. 
Catalano, P.M., Nizielski, S.E., Shao, J., Preston, L., Qiao, L., Friedman, J.E., 2002. Downregulated IRS-1 and PPARgamma in obese women with gestational diabetes: relationship to FFA during pregnancy. Am. J. Physiol. Endocrinol. Metab. 282, E522-533.

Coppack, S.W., 2001. Pro-inflammatory cytokines and adipose tissue. Proc. Nutr. Soc. 60, 349-356.

Coughlan, M.T., Oliva, K., Georgiou, H.M., Permezel, J.M., Rice, G.E., 2001. Glucoseinduced release of tumour necrosis factor-alpha from human placental and adipose tissues in gestational diabetes mellitus. Diabet. Med. 18, 921-927.

Cseh, K., Baranyi, E., Melczer, Z., Csákány, G.M., Speer, G., Kovács, M., Gerö, G., Karádi, I., Winkler, G., 2002. The pathophysiological influence of leptin and the tumor necrosis factor system on maternal insulin resistance: negative correlation with anthropometric parameters of neonates in gestational diabetes. Gynecol. Endocrinol. 16, 453-460.

Deroo B.J., Korach K.S., 2006. Estrogen receptors and human disease. J.Clin. Invest. 116, 561-570.

Dolinková, M., Dostálová, I., Lacinová, Z., Michalský, D., Haluzíková, D., Mráz, M., Kasalický, M., Haluzík, M., 2008. The endocrine profile of subcutaneous and visceral adipose tissue of obese patients. Mol. Cell. Endocrinol. 291, 63-70. 
Festa, A., Shnawa, N., Krugluger, W., Hopmeier, P., Schernthaner, G., Haffner, S.M., 1999. Relative hypoleptinaemia in women with mild gestational diabetes mellitus. Diabet. Med. 16, 656-662.

Foryst-Ludwig, A., Clemenz, M., Hohmann, S., Hartge, M., Sprang, C., Frost, N., Krikov, M., Bhanot, S., Barros, R., Morani, A., Gustafsson, J.A., Unger, T., Kintscher, U., 2008. Metabolic actions of estrogen receptor beta (ERbeta) are mediated by a negative cross-talk with PPARgamma. PLoS. Genet. 4, e1000108.

Friedman, J.E., Ishizuka, T., Shao, J., Huston, L., Highman, T., Catalano, P., 1999. Impaired glucose transport and insulin receptor tyrosine phosphorylation in skeletal muscle from obese women with gestational diabetes. Diabetes. 48, 1807-1814.

Gabbe, S.G., 1986. Gestational diabetes mellitus. N. Engl. J. Med. 315, 1025-1026.

Gao, X.L., Yang, H.X., Zhao, Y., 2008. Variations of tumor necrosis factor-alpha, leptin and adiponectin in mid-trimester of gestational diabetes mellitus. Chin. Med. J. (Engl). 121, 701705.

Greenberg, A.S., McDaniel, M.L., 2002. Identifying the links between obesity, insulin resistance and beta-cell function: potential role of adipocyte-derived cytokines in the pathogenesis of type 2 diabetes. Eur. J. Clin. Invest. 32, 24-34.

Havel, P.J., 2002. Control of energy homeostasis and insulin action by adipocyte hormones: leptin, acylation stimulating protein, and adiponectin. Curr. Opin. Lipidol. 13, 51-59. 
Heine, P.A., Taylor, J.A,, Iwamoto, G.A., Lubahn, D.B., Cooke, P.S., 2000. Increased adipose tissue in male and female estrogen receptor-alpha knockout mice. Proc. Natl. Acad. Sci. U S A. 97, 12729-12734.

Hennige, A.M., Stefan, N., Kapp, K., Lehmann, R., Weigert, C., Beck, A., Moeschel, K., Mushack, J., Schleicher, E., Häring, H.U., 2006. Leptin down-regulates insulin action through phosphorylation of serine-318 in insulin receptor substrate 1. FASEB. J. 20, 1206-1208.

Henson, M.C., Castracane, V.D., 2002. Leptin: roles and regulation in primate pregnancy. Semin. Reprod. Med. 20, 113-122.

Hernández Valencia, M., Zárate, A., 2005. Recent concepts in gestational diabetes' etiopathogenesis. Ginecol. Obstet. Mex. 73, 371-377.

Housa, D., Housová, J., Vernerová, Z., Haluzík, M., 2006. Adipocytokines and cancer. Physiol. Res. 55, 233-244.

Jansson, P.A., Eliasson, B., Lindmark, S., Eriksson, J.W., 2002. Endocrine abnormalities in healthy first-degree relatives of type 2 diabetes patients--potential role of steroid hormones and leptin in the development of insulin resistance. Eur. J. Clin. Invest. 32, 172-178.

Kautzky-Willer, A., Pacini, G., Tura, A., Bieglmayer, C., Schneider, B., Ludvik, B., Prager, R., Waldhäusl, W., 2001. Increased plasma leptin in gestational diabetes. Diabetologia. 44, 164-172. 
Kern, P.A., Ranganathan, S., Li, C., Wood, L., Ranganathan, G., 2001. Adipose tissue tumor necrosis factor and interleukin-6 expression in human obesity and insulin resistance. Am. J. Physiol. Endocrinol. Metab. 280, E745-E751.

Kim, C., Newton, K.M., Knopp, R.H., 2002. Gestational diabetes and the incidence of type 2 diabetes: a systematic review. Diabetes. Care. 25, 1862-1868.

Kirwan, J.P., Hauguel-De Mouzon, S., Lepercq, J., Challier, J.C., Huston-Presley, L., Friedman, J.E., Kalhan, S.C., Catalano, P.M., 2002. TNF-alpha is a predictor of insulin resistance in human pregnancy. Diabetes. 51, 2207-2213.

Kleiblová, P., Springer, D., Haluzík, M., 2006. The influence of hormonal changes during menstrual cycle on serum adiponectin concentrations in healthy women. Physiol. Res. 55, 661-666.

Kuzmicki, M., Telejko, B., Zonenberg, A., Szamatowicz, J., Kretowski, A., Nikolajuk, A., Laudanski, P., Gorska, M., 2008. Circulating pro- and anti-inflammatory cytokines in Polish women with gestational diabetes. Horm. Metab. Res. 40, 556-560.

Lamounier-Zepter, V., Bornstein, S.R., Kunes, J., Zicha, J., Krsek, M., Ehrhart-Bornstein, M., Ziegler, C.G., Kiessling, A., Funk, R.H., Haluzik, M., 2008. Adrenocortical changes and arterial hypertension in lipoatrophic A-ZIP/F-1 mice. Mol. Cell. Endocrinol. 280, 39-46. 
Lappas, M., Yee, K., Permezel, M., Rice, G.E., 2005. Release and regulation of leptin, resistin and adiponectin from human placenta, fetal membranes, and maternal adipose tissue and skeletal muscle from normal and gestational diabetes mellitus-complicated pregnancies. J. Endocrinol. 186, 457-465.

Lea, R.G., Howe, D., Hannah, L.T., Bonneau, O., Hunter, L., Hoggard, N., 2000. Placental leptin in normal, diabetic and fetal growth-retarded pregnancies. Mol. Hum. Reprod. 6, 763769.

Lepercq, J., Cauzac, M., Lahlou, N., Timsit, J., Girard, J., Auwerx, J., Hauguel-de Mouzon, S., 1998. Overexpression of placental leptin in diabetic pregnancy: a critical role for insulin. Diabetes. 47, 847-850.

Lim, S., Choi, S.H., Park, Y.J., Park, K.S., Lee, H.K., Jang, H.C., Cho, N.H., Metzger, B.E., 2007. Visceral fatness and insulin sensitivity in women with a previous history of gestational diabetes mellitus. Diabetes. Care. 30, 348-353.

Maghbooli, Z., Hossein-Nezhad, A., Rahmani, M., Shafaei, A.R., Larijani, B., 2007. Relationship between leptin concentration and insulin resistance. Horm. Metab. Res. 39, 903907.

Masuzaki, H., Ogawa, Y., Sagawa, N., Hosoda, K., Matsumoto, T., Mise, H., Nishimura, H., Yoshimasa, Y., Tanaka, I., Mori, T., Nakao, K., 1997. Nonadipose tissue production of leptin: leptin as a novel placenta-derived hormone in humans. Nat. Med. 3, 1029-1033. 
McNeely, M.J., Boyko, E.J., Weigle, D.S., Shofer, J.B., Chessler, S.D., Leonnetti, D.L., Fujimoto, W.Y., 1999. Association between baseline plasma leptin levels and subsequent development of diabetes in Japanese Americans. Diabetes. Care. 22, 65-70.

Meller, M., Qiu, C., Vadachkoria, S., Abetew, D.F., Luthy, D.A., Williams, M.A., 2006. Changes in placental adipocytokine gene expression associated with gestational diabetes mellitus. Physiol. Res. 55, 501-512.

Moller, D.E., 2000. Potential role of TNF-alpha in the pathogenesis of insulin resistance and type 2 diabetes. Trends. Endocrinol. Metab. 11, 212-217.

Naaz, A., Zakroczymski, M., Heine, P., Taylor, J., Saunders, P., Lubahn, D., Cooke, P.S., 2002. Effect of ovariectomy on adipose tissue of mice in the absence of estrogen receptor alpha (ERalpha): a potential role for estrogen receptor beta (ERbeta). Horm. Metab. Res. 34, 758-763.

Nathanielsz, P.W., Poston, L., Taylor, P.D., 2007. In utero exposure to maternal obesity and diabetes: animal models that identify and characterize implications for future health. Clin. Perinatol. 34, 515-526.

Pendegrass, M., Fayioni, E., DeFronyo, R., 1995. NIDDM and GDM: same disease, another name? Diabetes. Rev. 3, 556-583. 
Pfaffl, M.W., Horgan, G.W., Dempfle, L., 2002. Relative expression software tool (REST) for group-wise comparison and statistical analysis of relative expression results in real-time PCR. Nucleic. Acids. Res. 30, e36.

Pfaffl, M.W., 2001. A new mathematical model for relative quantification in real-time RTPCR. Nucleic. Acids. Res. 29, e45.

Pratley, R.E., Ren, K., Milner, M.R., Sell, S.M., 2000. Insulin increases leptin mRNA expression in abdominal subcutaneous adipose tissue in humans. Mol. Genet. Metab. 70, 1926.

Qiu, C., Williams, M.A., Vadachkoria, S., Frederick, I.O., Luthy, D.A., 2004. Increased maternal plasma leptin in early pregnancy and risk of gestational diabetes mellitus. Obstet. Gynecol. 103, 519-525.

Radaelli, T., Varastehpour, A., Catalano, P., Hauguel-de Mouzon, S., 2003. Gestational diabetes induces placental genes for chronic stress and inflammatory pathways. Diabetes. 52, 2951-2958.

Ranheim, T., Haugen, F., Staff, A.C., Braekke, K., Harsem, N.K., Drevon, C.A., 2004. Adiponectin is reduced in gestational diabetes mellitus in normal weight women. Acta. Obstet. Gynecol. Scand. 83, 341-347.

Salvatores, M., Gennarelli, G., Menato, G., Massobrio, M., 2006. Leptin as a possible marker of augmented metabolic risk during pregnancy. Minerva. Ginecol. 58, 1-10. 
Shahid, A., Lone, K.P., Saeed, S., Arslan, M., 2008. Male offspring of both diabetic parents have higher insulin resistance and serum leptin levels compared to those with one diabetic parent. Hormones. (Athens). 7, 313-319.

Simmons, D., Breier, B.H., 2002. Fetal overnutrition in polynesian pregnancies and in gestational diabetes may lead to dysregulation of the adipoinsular axis in offspring. Diabetes. Care. 25, 1539-1544.

Sivan, E., Whittaker, P.G., Sinha, D., Homko, C.J., Lin, M., Reece, E.A., Boden, G., 1998. Leptin in human pregnancy: the relationship with gestational hormones. Am. J. Obstet. Gynecol. 179, 1128-1132.

Steppan, C.M., Bailey, S.T., Bhat, S., Brown, E.J., Banerjee, R.R., Wright, C.M., Patel, H.R., Ahima, R.S., Lazar, M.A., 2001. The hormone resistin links obesity to diabetes. Nature. 409, 307-312.

Tanaka, M., Nakaya, S., Kumai, T., Watanabe, M., Tateishi, T., Shimizu, H., Kobayashi, S., 2001. Effects of estrogen on serum leptin levels and leptin mRNA expression in adipose tissue in rats. Horm. Res. 56, 98-104.

Wagenknecht, L.E., Langefeld, C.D., Scherzinger, A.L., Norris, J.M., Haffner, S.M., Saad, M.F., Bergman, R.N., 2003. Insulin sensitivity, insulin secretion, and abdominal fat: the Insulin Resistance Atherosclerosis Study (IRAS) Family Study. Diabetes. 52, 2490-2496. 
Wajchenberg, B.L., 2000. Subcutaneous and visceral adipose tissue: their relation to the metabolic syndrome. Endocr. Rev. 21, 697-738.

Wauters, M., Considine, R., Löfgren, A., Van Broeckhoven, C., Van der Auwera, J.C., De Leeuw, I., Van Gaal, L., 2000. Associations of leptin with body fat distribution and metabolic parameters in non-insulin-dependent diabetic patients: no effect of apolipoprotein E polymorphism. Metabolism. 49, 724-730.

Weyer, C., Funahashi, T., Tanaka, S., Hotta, K., Matsuzawa, Y., Pratley, R.E., Tataranni, P.A., 2001. Hypoadiponectinemia in obesity and type 2 diabetes: close association with insulin resistance and hyperinsulinemia. J. Clin. Endocrinol. Metab. 86, 1930-1935.

Yi, K.W., Shin, J.H., Seo, H.S., Lee, J.K., Oh, M.J., Kim, T., Saw, H.S., Kim, S.H., Hur, J.Y., 2008. Role of estrogen receptor-alpha and -beta in regulating leptin expression in 3T3-L1 adipocytes. Obesity (Silver Spring). 16, 2393-2399.

Yura, S., Sagawa, N., Itoh, H., Kakui, K., Nuamah, M.A., Korita, D., Takemura, M., Fujii, S., 2003. Resistin is expressed in the human placenta. J. Clin. Endocrinol. Metab. 88, 1394-1397. 
Table 1. Anthropometric characteristics of healthy pregnant women, patients with gestational diabetes mellitus (GDM) (A) and their newborns (B).

\begin{tabular}{|c|c|c|c|}
\hline A. MOTHERS & Controls $(\mathrm{N}=13)$ & GDM $(\mathrm{N}=10)$ & $P$-value \\
\hline BMI before pregnancy [kg.m $\left.{ }^{-2}\right]$ & $22.7 \pm 0.9$ & $\mathbf{3 0 . 1} \pm 2.3$ & 0.012 \\
\hline BMI $3^{\text {rd }}$ day after delivery $\left[\mathrm{kg} . \mathrm{m}^{-2}\right]$ & $25.5 \pm 1.0$ & $32.9 \pm 2.5$ & 0.025 \\
\hline$\%$ of body fat $3^{\text {rd }}$ day after delivery & $32.4 \pm 1.3$ & $39.6 \pm 2.4$ & 0.023 \\
\hline Age [years] & $33.1 \pm 1.3$ & $34.6 \pm 2.5$ & 0.569 \\
\hline Gestational age [days] & $276.9 \pm 1.6$ & $268.9 \pm 4.2$ & 0.055 \\
\hline B. NEWBORNS & Controls $(\mathrm{N}=13)$ & GDM $(\mathrm{N}=10)$ & $P$-value \\
\hline Birth weight [kg] & $3.42 \pm 0.14$ & $3.47 \pm 0.27$ & 0.838 \\
\hline Birth length [m] & $0.51 \pm 0.01$ & $0.49 \pm 0.01$ & 0.051 \\
\hline Birth wigth/length [kg.m $\left.{ }^{-1}\right]$ & $6.75 \pm 0.22$ & $7.10 \pm 0.45$ & 0.456 \\
\hline Gender [N = girls / boys $]$ & $8 / 5$ & $7 / 3$ & \\
\hline
\end{tabular}

Results are means \pm SEM; $\mathrm{N}=$ number of subjects; $p<0.05$ denoted statistical significant changes. 
Table 2. Maternal and fetal serum parameters in healthy pregnant women and patients with gestational diabetes mellitus (GDM) measured at the time of delivery.

\begin{tabular}{|c|c|c|c|}
\hline MATERNAL SERUM & CONTROLS $(\mathrm{N}=13)$ & GDM $(\mathrm{N}=10)$ & $P$-value \\
\hline Adiponectin $\left[\mu \mathrm{g} \cdot \mathrm{ml}^{-1}\right]$ & $24.5 \pm 2.33$ & $20.1 \pm 3.04$ & 0.3 \\
\hline Leptin [ng.ml $\left.{ }^{-1}\right]$ & $21.8 \pm 2.72$ & $39.6 \pm 8.11$ & 0.1 \\
\hline Resistin [ng.ml ${ }^{-1}$ ] & $10.9 \pm 0.58$ & $12.6 \pm 1.33$ & 0.2 \\
\hline Glucose $\left[\mathrm{mmol.} \mathrm{l}^{-1}\right]$ & $3.9 \pm 0.12$ & $5.5 \pm 0.82$ & 0.03 \\
\hline Insulin [mIU. $\left.{ }^{-1}\right]$ & $23.4 \pm 1.96$ & $\mathbf{1 4 4 . 8} \pm 64.56$ & 0.04 \\
\hline C-peptide [nmol..$\left.^{-1}\right]$ & $0.6 \pm 0.05$ & $1.0 \pm 0.29$ & 0.6 \\
\hline Glycated hemoglobin [\%] & $3.4 \pm 0.10$ & $\mathbf{4 . 1} \pm 0.21$ & 0.002 \\
\hline Triglycerides $\left[\mathrm{mmol}^{-1}{ }^{-1}\right]$ & $3.9 \pm 0.47$ & $3.5 \pm 0.27$ & 0.5 \\
\hline Estradiol [nmol.l $\left.{ }^{-1}\right]$ & $83.4 \pm 8.82$ & $74.1 \pm 11.93$ & 0.5 \\
\hline FETAL SERUM & CONTROLS $(\mathrm{N}=13)$ & GDM $(\mathrm{N}=10)$ & $P$-value \\
\hline Adiponectin $\left[\mu \mathrm{g} \cdot \mathrm{ml}^{-1}\right]$ & $76.1 \pm 12.99$ & $64.9 \pm 12.08$ & 0.6 \\
\hline Leptin [ng.ml ${ }^{-1}$ ] & $\mathbf{8 . 1} \pm 1.76$ & $24.3 \pm 6.44$ & 0.02 \\
\hline Resistin [ng.ml ${ }^{-1}$ ] & $11.0 \pm 1.46$ & $10.9 \pm 0.88$ & 0.96 \\
\hline Insulin [mIU. $\left.{ }^{-1}\right]$ & $18.4 \pm 2.17$ & $34.9 \pm 12.99$ & 0.2 \\
\hline
\end{tabular}


Table 3. Fold changes of relative gene expression levels in subcutaneous (SAT) and visceral (VAT) adipose tissue and in placenta from women with gestational diabetes mellitus (GDM) $(\mathrm{N}=10)$ relative to healthy pregnant women $(\mathrm{N}=13)$. Relative gene expression of the respective gene of the healthy pregnant group $=1$.

\begin{tabular}{lcccccc}
\hline GDM to control group expression & \multicolumn{2}{c}{ SAT } & \multicolumn{2}{c}{ VAT } & \multicolumn{2}{c}{ PLACENTA } \\
Gene & ExpR & $P$-value & ExpR & $P$-value & ExpR & $P$-value \\
\hline Leptin $(L E P)$ & 1.18 & 0.4 & $\mathbf{3 . 4 9}$ & $\mathbf{0 . 0 2}$ & 1.56 & 0.6 \\
Resistin $(R E T N)$ & 0.79 & 0.6 & 1.13 & 0.7 & 1.09 & 0.8 \\
Adiponectin $(A D I P O Q)$ & 0.74 & 0.07 & 0.81 & 0.6 & ND & \\
Adiponectin receptor 1 (ADIPORl) & 1.11 & 0.5 & 1.01 & 0.96 & 1.07 & 0.7 \\
Adiponectin receptor $2(A D I P O R 2)$ & 1.04 & 0.8 & 1.18 & 0.4 & 1.21 & 0.2 \\
PPAR-alpha $(P P A R-\alpha)$ & 0.76 & 0.3 & 0.76 & 0.4 & NE & \\
TNF-alpha (TNF- $\alpha)$ & 1.51 & 0.4 & 0.97 & 0.9 & 1.32 & 0.4 \\
CD68 & 1.18 & 0.6 & 0.89 & 0.3 & 1.10 & 0.6 \\
Interleukin-6 $(I L-6)$ & $\mathbf{6 . 3 2}$ & $\mathbf{0 . 0 1}$ & 2.66 & 0.1 & 0.98 & 0.9 \\
Interleukin-8 $(I L-8)$ & $\mathbf{4 . 7 5}$ & $\mathbf{0 . 0 3}$ & 1.26 & 0.6 & 0.95 & 0.9 \\
Estrogen receptor alpha $(E R \alpha)$ & $\mathbf{0 . 5 2}$ & $\mathbf{0 . 0 4 5}$ & 1.46 & 0.1 & 1.75 & 0.1 \\
Estrogen receptor beta $(E R \beta)$ & $\mathbf{0 . 6 8}$ & $\mathbf{0 . 0 3 3}$ & 1.21 & 0.4 & 1.07 & 0.8 \\
\hline ExpR expression ratio; ND not detected; NE & not estimated; & $p<0.05$ & denoted statistical \\
significant changes. & & & & & &
\end{tabular}


Table 4. The comparison of the relative gene expression (normalized to 3 housekeeping genes) of target genes in visceral adipose tissue (VAT) and placenta relative to subcutaneous adipose tissue (SAT) with (CONTROL and GDM subgroups) or without (ALL subjects together) the dependency of GDM status. Relative expression of respective gene in SAT $=1$.

\begin{tabular}{|c|c|c|c|c|c|c|}
\hline \multirow{2}{*}{$\frac{\text { VAT }}{\text { Gene }}$} & \multicolumn{2}{|c|}{ ALL } & \multicolumn{2}{|c|}{ CONTROLS } & \multicolumn{2}{|c|}{ GDM } \\
\hline & ExpR & $P$-value & ExpR & $P$-value & ExpR & $P$-value \\
\hline Leptin $(L E P)$ & 0.08 & 0.001 & 0.06 & 0.001 & 0.16 & 0.001 \\
\hline Resistin (RETN) & 0.27 & 0.001 & 0.25 & 0.001 & 0.35 & 0.1 \\
\hline Adiponectin $(A D I P O Q)$ & 0.40 & 0.001 & 0.38 & 0.003 & 0.42 & 0.004 \\
\hline Adiponectin receptor 1 (ADIPORl) & 0.73 & 0.01 & 0.77 & 0.03 & 0.71 & 0.2 \\
\hline Adiponectin receptor 2 (ADIPOR2) & 0.77 & 0.03 & 0.73 & 0.04 & 0.83 & 0.3 \\
\hline PPAR-alpha $(P P A R-\alpha)$ & 1.07 & 0.7 & 1.02 & 0.9 & 1.02 & 0.97 \\
\hline TNF-alpha $(T N F-\alpha)$ & 0.62 & 0.1 & 0.73 & 0.3 & 0.47 & 0.1 \\
\hline$C D 68$ & 0.88 & 0.4 & 0.97 & 0.9 & 0.74 & 0.2 \\
\hline Interleukin-6 (IL-6) & 1.24 & 0.7 & 1.85 & 0.3 & 0.78 & 0.7 \\
\hline Interleukin-8 (IL-8) & 0.31 & 0.03 & 0.55 & 0.4 & 0.15 & 0.002 \\
\hline Estrogen receptor alpha $(E R \alpha)$ & 0.59 & 0.01 & 0.38 & 0.001 & 1.06 & 0.8 \\
\hline Estrogen receptor beta $(E R \beta)$ & 0.40 & 0.001 & 0.31 & 0.001 & 0.56 & 0.001 \\
\hline PLACENTA & \multicolumn{2}{|c|}{ ALL } & \multicolumn{2}{|c|}{ CONTROLS } & \multicolumn{2}{|c|}{ GDM } \\
\hline Gene & $\operatorname{ExpR}$ & $P$-value & $\operatorname{ExpR}$ & $P$-value & ExpR & $P$-value \\
\hline Leptin $(L E P)$ & 0.28 & 0.002 & 0.24 & 0.006 & 0.32 & 0.1 \\
\hline Resistin (RETN) & 1.12 & 0.7 & 1.01 & 0.98 & 1.40 & 0.5 \\
\hline Adiponectin $(A D I P O Q)$ & ND & & ND & & ND & \\
\hline Adiponectin receptor 1 (ADIPORI) & 3.18 & 0.001 & 3.30 & 0.001 & 3.18 & 0.001 \\
\hline Adiponectin receptor 2 ( $A D I P O R 2)$ & 0.79 & 0.01 & 0.73 & 0.002 & 0.86 & 0.4 \\
\hline PPAR-alpha $(P P A R-\alpha)$ & $\mathrm{NE}$ & & $\mathrm{NE}$ & & $\mathrm{NE}$ & \\
\hline TNF-alpha $(T N F-\alpha)$ & 1.10 & 0.7 & 1.15 & 0.7 & 1.01 & 0.98 \\
\hline$C D 68$ & 0.60 & 0.004 & 0.61 & 0.02 & 0.57 & 0.1 \\
\hline Interleukin-6 (IL-O) & 0.38 & 0.02 & 0.82 & 0.7 & 0.13 & 0.001 \\
\hline Interleukin-8 (IL-8) & 0.09 & 0.001 & 0.18 & 0.01 & 0.04 & 0.001 \\
\hline Estrogen receptor alpha $(E R \alpha)$ & 0.12 & 0.001 & $\mathbf{0 . 0 7}$ & 0.001 & 0.24 & 0.005 \\
\hline Estrogen receptor beta $(E R \beta)$ & 0.02 & 0.001 & 0.01 & 0.001 & 0.02 & 0.001 \\
\hline
\end{tabular}


ExpR expression ratio; NE not estimated; ND not detected; $p<0.05$ denoted statistical significant changes. 
Figure Legends:

Figure 1. The whisker box plot of statistically significant $(\mathrm{p}<0.05)$ changes of the relative gene expression ratio (normalized to 3 housekeeping genes) in GDM group compared to controls in VAT (black color) and SAT (grey color). The relative gene expression of the respective gene in control group $=1$.

Figure 2. The log scale scatter plot of relative gene expression (compared to $B 2 M$ ) of all analyzed genes in SAT (squares), VAT (triangles) and placenta (circles) in GDM (white color) and control group (black color). The expression of $B 2 M$ gene $=1$. 


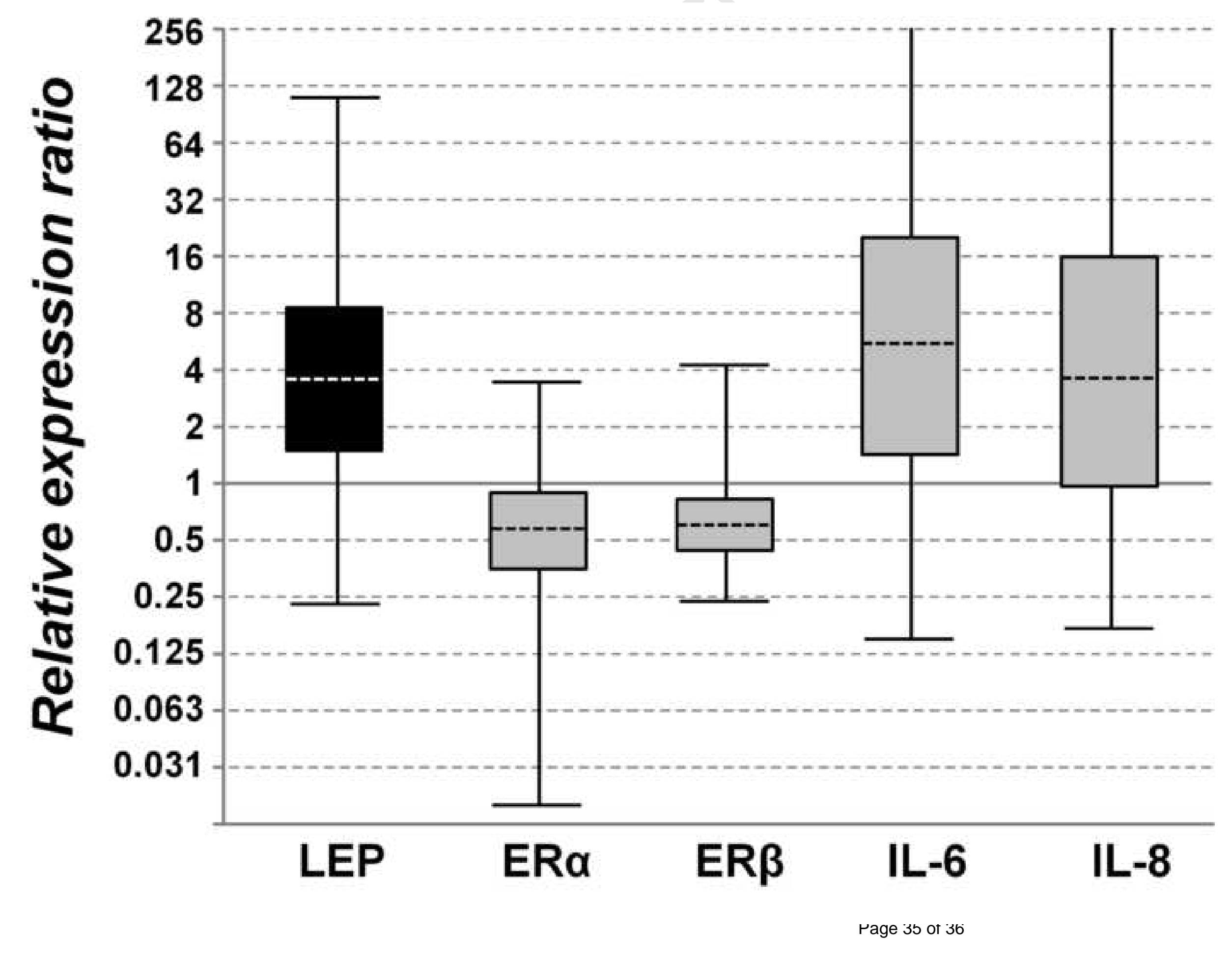

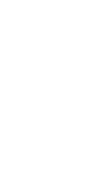




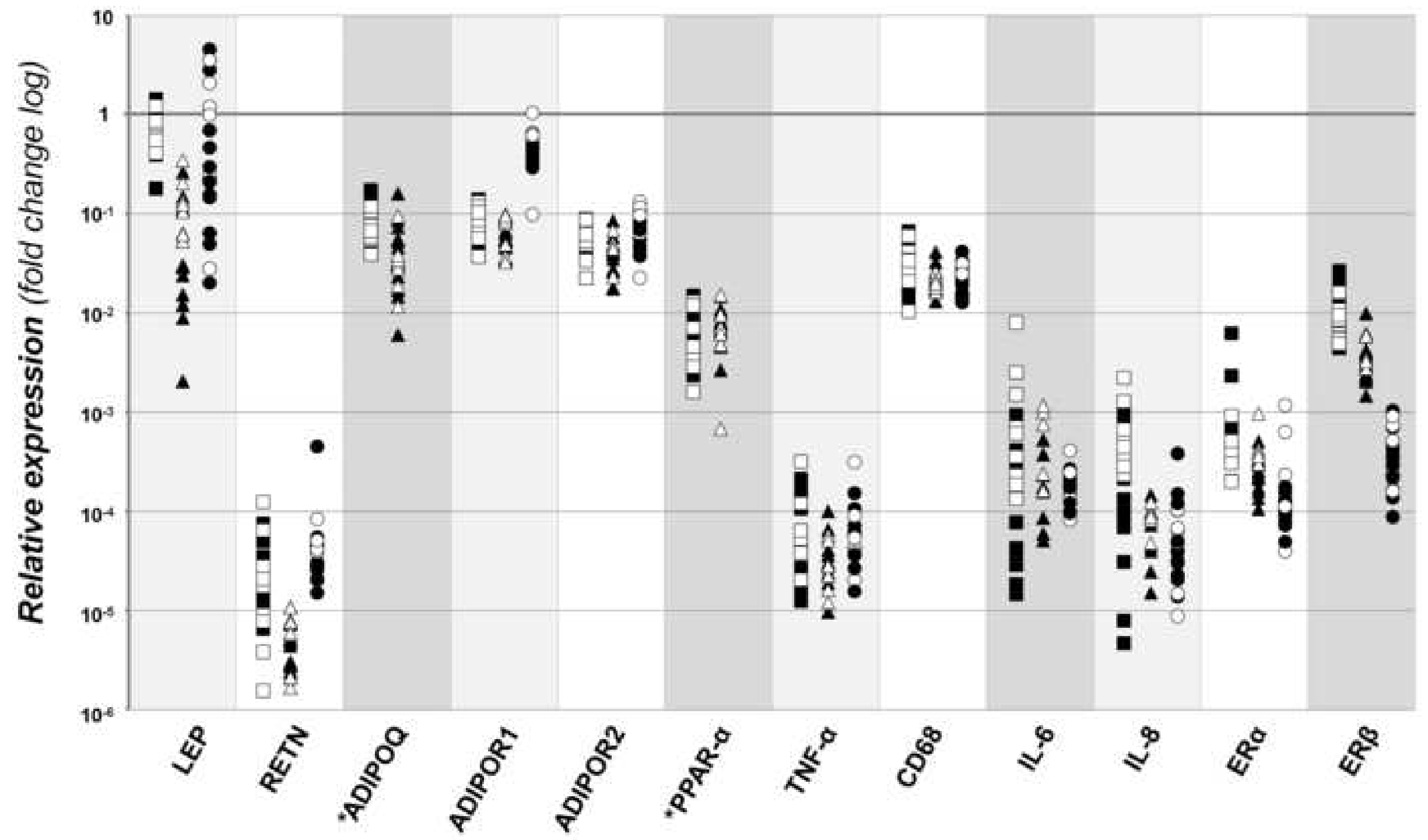

